\title{
Ortadoğu ve Kuzey Afrika'da Kurumsal Yapının Kadınların İş Gücüne Katılım Oranı Üzerindeki Etkisi
}

\author{
The Effects of Institutional Structure on Labor \\ Participation of Women in The Middle East and \\ North Africa
}

Tahsin Yamak*, Emre Saygın**, Adem Gök***

\section{Özet}

Kadın nüfusu, küresel nüfusun yarısını, toplam küresel iş gücü miktarının ise yaklaşık yüzde otuz dokuzluk kısmını oluşturmaktadır. Bu oranın, toplumsal hayatta son derece büyük dönüşümlerin yaşandığı doksanlı yıllardan günümüze önemli bir değişiklik göstermemesi dikkat çekmektedir. Zira kadının siyasal, sosyal ve ekonomik hayata daha çok katılması bir yandan gelecek nesillerin daha nitelikli ve sağlıklı bir şekilde yetiştirilmesi bir yandan da toplumun genel refah düzeyinin yükseltilmesi bakımından önem taşımaktadır. Bu çalışmada, benzer nitelikli diğer çalışmalardan farklı olarak siyasal, sosyal ve ekonomik yapının temel dinamikleri ve teşvik edici unsurlarını oluşturan kurumların kadın istihdamı üzerindeki etkilerinin incelenmesi hedeflenmiştir. Bu doğrultuda kadın istihdamının son derece düşük düzeyde olduğu Ortadoğu ve Kuzey Afrika ülkelerinde kadınların iş gücüne katılım oranının belirleyicileri, 1990-2016 dönemi için Fark ve Sistem GMM yöntemleri kullanılarak araştırılmıştır. Netice olarak, kurumsal yapı

* Dr., Kamu İç Denetçisi, tahsinyamak@gmail.com, orcid.org/0000-0001-88317448

** Dr., Kamu İç Denetçisi, sayginemre@gmail.com, orcid.org/0000-0003-29391562

*** Dr. Öğr. Üyesi, Kırklareli Üniversitesi, Kırklareli, Türkiye, adem.gok@klu. edu.tr, orcid.org/0000-0002-3786-2507

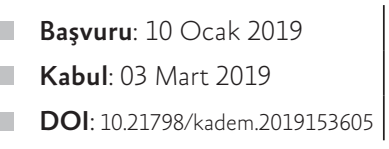

This work is licensed under the Creative Commons Attribution 4.0 International License.

Cite this article as: Yamak, T., Saygın, E. \& Gök, A. (2019). Ortadoğu ve Kuzey Afrika'da Kurumsal Yapının Kadınların Iş Gücüne Katılım Oranı Üzerindeki Etkisi. Kadem Kadın Araştırmaları Dergisi, Vol. 5, No. 1. s. 67-97. 
göstergesi olarak modele dahil edilen ve ülkedeki cinsiyet adaleti ve fırsat eşitliği ile iş bulma özgürlüğü gibi çeşitli toplumsal hürriyetleri ifade eden sivil özgürlükler değişkeninin, kadın istihdamı üzerinde pozitif ve anlamlı etkilerinin bulunduğu sonucuna ulaşılmıştır.

\begin{abstract}
The female population constitutes half of the global population and approximately thirty-nine percent of the total global labor force. It is noteworthy that this rate has not showed a significant change from the 1990s to the present day, when great changes and transformations took place in social life. Women's participation in political, social and economic life is extremely important in order to raise future generations in a more qualified and healthy way and to increase the general welfare level of the society. In this study, it is aimed to examine the effects of the institutions that constitute the main dynamics and incentive elements of political, social and economic structure on women's employment. In this respect, the determinants of female labor force participation in the countries of Middle East and North Africa, where the employment of women are extremely low, were investigated by using Difference and System GMM methods for the period of 1990-2016. As a result, it has been concluded that the civil liberties variable, which is included in the model as institutional structure indicator expressing various social freedoms such as gender justice, equal opportunies, andfreedom of employment in the country, have a positive and significant effect on women's employment.
\end{abstract}

\title{
Extended Abstract
}

The female population constitutes half of the global population and approximately thirty-nine percent of the total global labor force. It is noteworthy that this rate did not show a significant change from the nineties to the present day, when great changes and transformations took place in social life. On the one hand, more involvement of women in political, social and economic life is important for raising future generations in a more qualified and healthy way and raising the general welfare level of the society on the other.

In this study, it is aimed to investigate the effects of the institutions that constitute the incentive elements of political, social and economic structure on women's employment. In this respect, the determinants of female labor force participation in the countries of Middle East and North Africa, where the employment of women are extremely low, were investigated by using Difference and System GMM methods for the period of 1990-2016. Within this framework, 
the effects of the formal arrangements created by societies and the institutional structure indicating the whole of the informal habits that continue in the historical continuity in a way that will make a unique contribution to the literature are also evaluated.

Women's Labor Force Participation Rate (lfp) is included in the model as a dependent variable; the institutions defined as rules of the game or generally accepted forms of habit are also examined under the heading Political Freedom (pol) and Civil Liberties (civ). In this context, the institutional structure represents the aim and main hypothesis of the study and it is obtained from Freedom House. According to the estimation results, political freedoms (pol) have negative significant effect on female labor force participation in contrast to the hypothesis 1 , and civil liberties (civ) has positive significant effect on female labor force participation in favor of the hypothesis 2. It is found that GDP per capita (gdp) and trade openness (trd) have positive significant effect on female labor force participation rate in accordance with hypothesis 3 and 4, respectively. Urbanization rate (urb) has positive significant effect on female labor force participation in favor of the hypothesis 5. Fertility rate (fer) and schooling rate (ens) have negative significant effect on female labor force participation rate in favor of hypothesis 6 and in contrast to hypothesis 7 . On the other hand, it is found that there was no significant relationship between contributing family workers (fam) and female labor force participation rate.

In countries where democratic representation mechanisms are developed, it is highly probable that there exists a positive relationship between political rights and female labor force participation rate since it has the opportunity to implement institutional arrangements to encourage female labor force participation in connection with the achievement of political rights. However, some improvements in democratic representation have been observed in the Middle East and North African countries. However, the values of the gender-based division of labor dominate the social life and social policy environment and they prevent working life from becoming a political field that produces positive discrimination against women. Besides, the shaping of regional economies around the rentier relationship cycle, the fact that women with a high standard of living are not willing to participate in employment, and that they have only limited demands on political representation and comfort of life are mentioned as features that restrict women's employment. All these reasons explain the negative impact of political freedoms (pol) on women's labor force participation (lfp) in the Middle East and North Africa. 
It is expected that the demand for labor force participation will increase with the development and expansion of civil liberties (civ) including individualization, personal liberties, right of expression and right to organize. In this context, although there are no significant improvements in the civil liberties and labor force participation rate in the Middle East and North African countries, the partial transformation in the economic structure and the expansion of various social freedoms such as gender and equal opportunities and freedom of employment have positive and significant effects on women's employment.

On the one hand, the fact that women stay away from economic life prevents the economy from reaching its potential size, and on the other hand, it prevents the social structure from being established in a healthy way. However, it is known that women's increased participation in employment is not sufficient to ensure economic growth exclusively. At this point, policies that promote growth in women-friendly sectors are important. In this context, it is important to prioritize policies that will promote women's employment in the service sector, which is the main driving force of growth, and where the higher skilled workforce is often employed. This will eliminate the social and cultural constraints that prevent women from joining the labor force.

It is obvious that the participation of women in economic activity in the Middle East and North Africa region and the many social benefits brought about by it will not be fully realized without a significant change in the structure and gender-based attitudes of production. In this context, in order to increase women's employment in the Middle East and North African countries, it is important to establish a legal framework for gender equality, to introduce women's security regulations on income security and to implement decent work practices. With the higher participation of women in economic life in the Middle East and North Africa, the natural resource-dependent economic structure can be diversified, economic growth and development can be achieved and income distribution justice can be provided in the long term. In addition, social stability in the region can be ensured by reducing the high blood pressure caused by the Arab Revolts which started at the end of 2010 and continue to exercise its influence on the whole region.

Anahtar Kelimeler: Ortadoğu, Kadın İş Gücü Katılımı, Kurumsal Yapı, Ekonomi Politik, Panel Veri.

Keywords: The Middle Eastand North Africa, Women's Labor Participation, Institutional Structure, Political Economy, Panel Data.

JEL Sınıflandırması / Classification: N35, J21, E02, C33. 


\section{Giriş}

Üretim kavramı, insan ihtiyaçlarını karşılamak ve böylelikle tatmin/fayda yaratmak maksatlı her türlü faaliyeti ifade etmekte olup, sınırlı üretim faktörleri ile sayısız ihtiyacın bir denge içerisinde uyumlaştırılmasına yönelik gerçekleştirilen mal ve hizmet istihsali olarak tanımlanabilir. Bu bağlamda, mal ve hizmet üretimi için gerekli faktörler toprak/doğal kaynaklar, emek/iş gücü, sermaye ve müteşebbis/girişimcidir. Bununla birlikte küçük topluluklarda ihtiyaçların nispeten daha sınırlı ve daha az karmaşık bir üretim faaliyeti yoluyla karşılanabildiği bilinmekte; birlikte yaşama olgusu ile hacmi genişleyen kapsamlı ihtiyaçların ise üretim artışını optimum düzeye çıkartabilecek şekilde iş süreçlerinin re-organizasyonu gerekli kıldığı genel kabul görmektedir.

Tarımsal üretimin yoğun olarak yapıldı̆̆ı İlkçă̆'dan itibaren en stratejik üretim faktörü olarak doğal kaynaklar/toprak ön plana çıkmakta iken; coğrafi keşifler, kolonyalizm, ticari kapitalizm gibi önemli gelişmeler çerçevesinde dönüşen ekonomik ve siyasal sistemler ile birlikte üretim faktörlerine atfedilen stratejik önem zaman içinde değişime uğramıştır. Bu alandaki en büyük dönüşümün, Kıta Avrupası'nda başlayan Reform, Rönesans ve Aydınlanma dönemlerinin entelektüel tesiri altında XVIII'inci yüzyılın ortalarından itibaren siyasal ve toplumsal alana ait kavramların yeniden sorgulanmasıyla birlikte yaşandığına şüphe yoktur. Bu dönüşümle birlikte süregelen demografik gelişmeler, bilim ve teknoloji alanında yaşanan değişimler, finans, bankacılık ile ticaret ve tarım sektöründe gerçekleşen önemli dönüşümlerin etkisi altında ortaya çıkan ve makineleşme ekseninde kristalize olan Sanayi Devrimi’nin başlamasına neden olmuştur.

Birçok karmaşık tarihsel koşulun tesiri altında meydana gelen Sanayi Devrimi, siyasal ve toplumsal alandaki yansımalarının yanında, büyük teknolojik gelişmelerin etkisi ile ekonomik sistemin işleyişinde muazzam değişiklikler meydana getirmiştir. Makineleşmenin ortaya çıkardığı verimlilik artışı, yeni üretim metotlarındaki gelişmeler ile birlikte üretim faktörlerinden emeğe olan talebi arttırmış, bu bağlamda yeni bir toplumsal sınıf olarak ortaya çıkan işçi 
sınıfı, sadece erkekleri değil kadınları ve hatta çocukları da içerisine alacak şekilde genişlemiştir.

Ekonomik yapıda meydana gelen bu dönüşüm ile birlikte iş gücü piyasasında kendilerine daha çok yer bulabilen, ancak düşük ücretli işlere ve enformel/kayıt dışı sektörlerde çalışmaya razı olmak durumunda kalan kadınlar; modernleşme ve kentleşme ile birlikte eğitim imkânları ve istihdam koşullarında elde ettikleri seviyeyi, XX'nci yüzyılda bütün dünyayı etkisi altına alan küreselleşme olgusunun dinamik etkisi altında daha nitelikli ve yüksek ücretli istihdam olanaklarına tahvil etmişlerdir. Bu durum kadın istihdamının sürdürülebilir ekonomik kalkınmanın önemli bir unsur olarak ele alındığı geniş bir literatürün oluşmasını da sağlamiştır.

$\mathrm{Bu}$ alanda yapılan çalışmalar incelendiğinde, kadın istihdamının (ya da kadınların iş gücüne katılım oranının) genellikle sosyo-demografik faktörler, makroekonomik değişkenler ile küreselleşmeye ilişkin diğer değişkenler etrafında incelendiği görülmektedir. Ancak bu çalışmada, diğer çalışmalardan farklı olacak şekilde kadınların iş gücüne katılımının belirleyici bir unsuru olarak, "bir toplumda oynanan oyunun kuralları" olarak tanımlanan, bir ülkenin istihdam yapısının teşekkül etmesinde de önemli bir etkisi bulunan ve politik yapı, ifade özgürlüğü, hukukun üstünlüğü, piyasaya yönelik düzenlemelerin kalitesi gibi unsurları kapsayan siyasal, toplumsal ve ekonomik kurumların etkisi Ortadoğu ve Kuzey Afrika ülkeleri özelinde araştırmaya konu edilmiştir.

$\mathrm{Bu}$ teorik çerçeve ekseninde şekillenen çalışmanın ilk bölümünde kadınların iş gücüne katılımı küresel gelişmeler bağlamında ele alınmakta; ikinci kısımda kadın istihdamının belirleyicilerine dair teorik ve ampirik çalışmalar kısaca açıklanmakta ve son bölümde Ortadoğu ve Kuzey Afrika ülkelerinde,1990-2016 dönemi için kadınların iş gücüne katılımının kurumsal belirleyicilerinin tespitine yönelik ampirik bir uygulamaya yer verilmektedir. Nihayet sonuç bölümünde bulgulara ilişkin açıklamalar verilip, bazı öneriler sunulmak suretiyle çalışma sonlandırılmaktadır. 


\section{Kadın İş Gücü ve İstihdamı: Devlet, Toplum ve Ekonomi}

XVIII'nci yüzyılda Kıta Avrupası'nda başlayan ve özellikle iktisadi sistemler üzerindeki etkisi ile dünya genelindeki bütün coğrafi bölgeleri ve ülkeleri tesiri altına alan sanayi devrimi, bilimsel ve teknolojik gelişmenin sağladığı avantajların ekonomik yapıya aktarılması suretiyle mal ve hizmet üretiminde önemli verimlilik artışları sağlayarak ülkelerin sektörel bazda üretim hacimlerinin artmasına ve form değiştirmesine neden olmuştur. Bu bağlamda, tarım sektörünün milli gelir içerisindeki payı gerilerken, sanayi ve hizmetler sektöründe ise artışlar meydana gelmiştir. Seri üretime imkân veren buluşların ekonomik yapıya entegre edilmesi ile büyük miktarlarda üretimlerin yapılabildiği bu dönemde, ülke ekonomileri diğer yandan dış ticarette önemli avantajlar elde etmiş, bu durum ise lojistik alanında meydana gelen dönüşümlerin dinamik etkisi altında küresel ticaret hacminin yükselmesine sebebiyet vermiştir. Devrimin ekonomik alana dair bir diğer etkisi ise yüksek sermaye birikimine neden olması ile üretim faktörlerinden birisi olan "girişimci/müteşebbis"in üretimden aldığ̣ payın artmasına diğer bir ifade ile kârının yükselmesine neden olmasıdır (Küçükkalay, 2016: 478-487).

Bunun yanı sıra, devrimin bir diğer etkisi ise yeni üretim ve istihdam alanlarının oluşmasına/genişlemesine sebebiyet vermesi ile bu durumun toplumsal ve demografik yapıda meydana getirdiği kritik değişikliğe dair olacaktır. Şöyle ki, artan üretim faaliyetlerinde, üretim için gerekli faktörlerinden emeğe/iş gücüne olan talep önemli ölçüde artmış, bu bağlamda öncelikle erkek iş gücü olmak üzere kadın iş gücü üretim faaliyetleri içerisinde daha çok rol almaya başlamıştır. Devrim öncesi, toplumsal sınıflaşmanın ve egemen ekonomik sistemin araçları içerisinde erkek iş gücüne nazaran genellikle ücretsiz aile iş̧̧iliği ya da yarı zamanlı, güvencesiz iş koşullarında ve oldukça sınırlı alanlarda istihdam edilen kadınlar, devrim sonrasında -bir sosyal sınıf olarak- ücretli bir şekilde işçi sınıfı içerisinde belirginleşmeye/yoğunlaşmaya başlamışlardır. Ancak söz konusu dönemde, iş̧̧i sınıfına ödenen düşük ücretler, kötü çalışma 
koşulları ile bu kesimin üretimden aldığı son derece düşük pay, iş ve işçi hakları ile eşit yurttaşlık bağlamında iyileştirici önlemlere yönelik düşünsel, siyasal ve hukuki düzenlemelerin de öncüsü olmuştur. İfade edilen bu hususlar ise kadının toplumsal faaliyetler içerisindeki temsil düzeyini arttırmış, siyasal ve ekonomik aktivitelere dair etkinliğini yükseltmiştir (Giddens, 2018: 14-15; Özer \& Biçerli, 2003/2004: 56).

Tarım devrimi ile sanayi devrimi sonrası insanlık tarihinin üçüncü büyük dönüşümünü ifade eden, sanayi toplumundan bilgi toplumuna geçişi temsil eden ve milenyumu şekillendiren küreselleşme sürecinde, özellikle bilgi-iletişim teknolojilerinde yaşanan büyük gelişim, üretim teknolojilerinin değişmesine bağlı olarak üretimin ve üretim faktörlerinin yapısal özelliklerinin yeniden şekillenmesine sebebiyet vermiştir. Dünya genelinde sosyal, siyasal ve ekonomik ilişkilerin yoğunlaştığı, karmaşıklaştığı ve âdeta dünyanın tek bir pazar olarak kurgulandığı iş bu süreçte, insanlar tarafindan oluşturulan ve ekonomik aktörler arasındaki ilişkileri şekillendiren, yönlendiren ve tanzim eden, genel kabul görmüş alışkanlık biçimleri olarak tanımlanan ve son yıllarda mülkiyet hakları, sivil ve siyasal özgürlükler, hukukun üstünlüğü, yolsuzluktan korunma, siyasal istikrar gibi kavramlar ile genişleyen bir yelpazede tanımlanan kurumlar ile bu kurumların meydana getirdiği ve ekonomik faaliyetlerin gelişimini temin eden çeşitli unsurlar olarak tanımlanan kurumsal yapılar da bu süreçte büyük oranda değişime/ dönüşüme uğramıştır. Tüm bu siyasi/ekonomik/sosyal ve kurumsal gelişmeler/değişimler ekseninde devlet ve toplum ilişkilerinde yaşanan büyük dönüşüm ise bir yandan ekonomik aktiviteleri, aktörleri ve performansı etkilerken diğer yandan, iş gücü/emek piyasasının da önemli ölçüde değişimine neden olmuştur (Fischer, 2013: 1-2; Polanyi, 2008; Sönmez, 2006:179; Çetin, 2012: 44).

Daha önce ifade edildiği üzere, sanayi devrimi sonrası gerek ekonomik gerekse de toplumsal hayata dair rollerinde başkalaşım yaşayan ve ücretli şekilde emek piyasasında kendilerine daha çok yer bulan kadınlar, küreselleşme sürecinin esnek üretim biçimlerine ve çalışma saatlerine imkân tanıyan organizasyonel gelişimi altında, 
özellikle de finansal hareketlerin serbestleşmenin bir sonucu olarak yeni finansal kurumların/kuruluşların (banka ve sigorta şirketleri vb.) diğer bir ifade ile hizmet sektörünün son derece büyüdüğü bir atmosferde, iş hayatına daha yoğun şekilde katılabilmişlerdir. Bu durum, genel olarak kadınların eğitim seviyelerinin yükselmesine, siyasal ve hukuki haklarının genişlemesine, cinsiyet ayrımcılığının azalmasına dair sosyal ve toplumsal düzenlemelerin hayata geçmesine ve sosyo-kültürel statülerinin yükselmesine neden olmuş, diğer yandan kadının aile içerisindeki rolünün ve sorumluluklarının yeniden tanımlanmasına ve değişmesine sebebiyet vermiştir (World Bank, 2011; Giddens, 2018; Wacker, Cooray \& Gaddis, 2017; Demirtaş ve Yayla, 2017).

Ancak, tüm bu süreçlerle birlikte ortaya çıkan ve ekonomik yapıyı önemli ölçüde değiştiren hususlar her ne kadar kadın iş gücüne olan talebi arttırmışsa da esasen kadınlar, uzun zamandır süregeldiği üzere düşük ücretli ve sosyal güvencesi eksik işlerde istihdam edilmiş; özellikle az gelişmiş ya da gelişmekte olan ülkeler daha yoğun şekilde bulunan emek faktörü -ve özellikle de kadın emeği- genel olarak neo-liberal politikaların öncelendiği serbest piyasa sisteminden istenilen/beklenilen ölçüde fayda sağlayamamış, üretimden aldığı pay ise yetersiz düzeyde kalmıştır (Gaddis \& Klasen, 2014; Kılınç, 2015; Karagül, 2014).

Bu noktada, öncelikle dünya ölçeğinde akabinde Ortadoğu ve Kuzey Afrika ülkeleri özelinde bir değerlendirme yapılmak suretiyle kadın iş gücünün ve kadınların iş gücüne katılım oranlarının tarihsel gelişimini izlemek yerinde olacaktır. 
Şekil 1: Dünya'da Kadın İş Gücü Miktarı, \%Toplam İş Gücü (1990-2017)

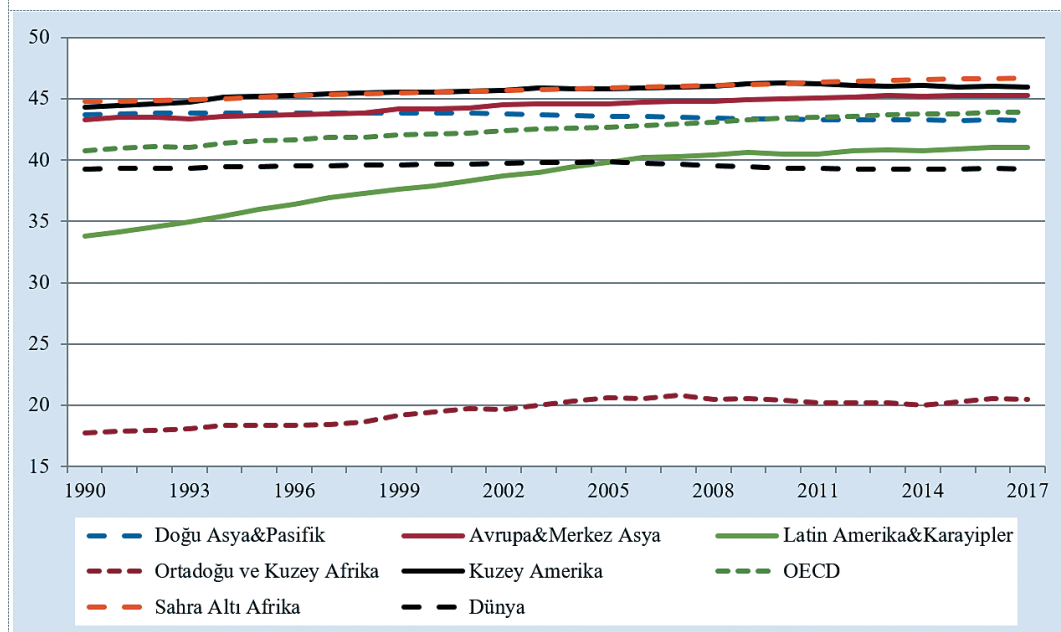

Kaynak: World Bank (2018), World Development Indicators, http://databank.worldbank.org/data/repor ts.aspx?source=World-Development-Indicators(Erişim: 22.09.2018)

Dünya genelinde kadın iş gücü büyüklüğüne ilişkin olarak hazırlanan Şekil 1 incelendiğinde, küreselleşme olgusunun yerleşik hale geldiği ve bilgi teknolojilerindeki gelişmelerin hızlandığı 1990'lardan günümüze, dünya genelinde kadınların toplam iş gücü ağırlığı içindeki oransal büyüklükleri önemli/kayda değer bir artış gösterebilmiş değildir. Bu bağlamda gözle görülür bir gelişim trendi, \%33’ler seviyesinde bulunan kadın iş gücü oranının \% 41’ler seviyesine yükseldiği Latin Amerika ve Karayipler bölgesinde görülmektedir. Diğer bölgeler \% 40-45 seviyesinde yatay bir seyir takip etmişlerdir. Gerek dünya gerekse diğer bölge ortalamalarından oldukça düşük bir düzeyde yer alan Ortadoğu ve Kuzey Afrika bölgesinde de 90’lı yılların başında \%17'ler düzeyinde bulunan kadın istihdamının, yaklaşık 30 yıllık süreçte sadece \% 3’lük bir artış göstererek \% 20’ler düzeyine yükselmiş ve böylece dünya ortalaması olan \% 40’lar seviyesinin ancak yarısına erişebilmiştir. 


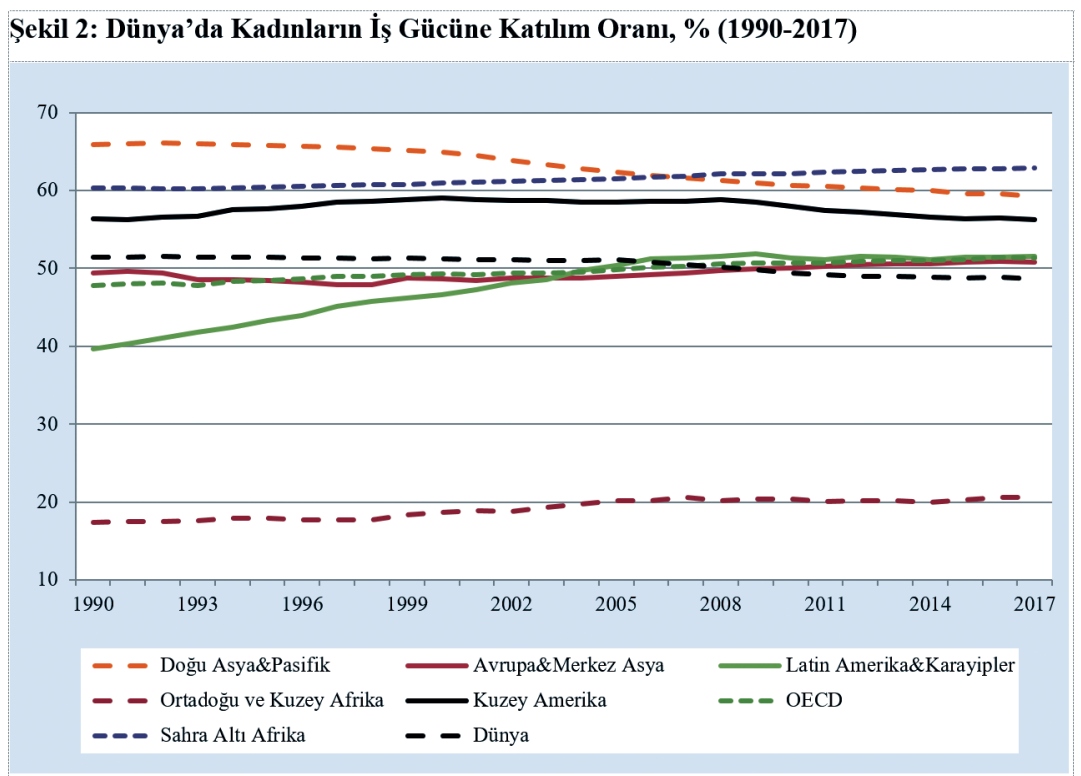

Kaynak: World Bank (2018), World Development Indicators, http://databank.worldbank.org/data/repor ts.aspx?source=World-Development-Indicators(Erişim: 22.09.2018)

Diğer yandan, çalışabilir durumda olan kadınların ne kadarının emek arzına katıldığını ifade eden kadın iş gücüne katılım oranlarına ${ }^{1}$ ilişkin veriler incelendiğinde (Bkz. Şekil 2), dünya genelinde çalışabilir durumda bulunan kadınların genel olarak yarısının emek piyasasına katıldığ̣ ve bu durumun 90'lı ylllardan günümüze kısmen de olsa azalış trendi içerisinde bulunduğu gözlemlenmektedir. Bu noktada Şekil 1 ile uyumlu olacak şekilde kadınların iş gücüne katılım oranı Latin Amerika ve Karayipler bölgesinde yıllar itibariyle bir artış eğilimi göstermiş, Ortadoğu ve Kuzey Afrika ise kadın istihdamında olduğu gibi kadınların iş gücüne katılım oranlarında da dünya ortalamasına yaklaşamamıştır (Moghadam, 2011).

1 İ̧ gücüne katılım oranları ve hesaplanmasına ilişkin detaylı bilgi için bkz. ILO, Labour force participation rate, https://www.ilo.org/ilostat-files/ Documents/description_LFPR_EN.pdf (20.09.2018) 


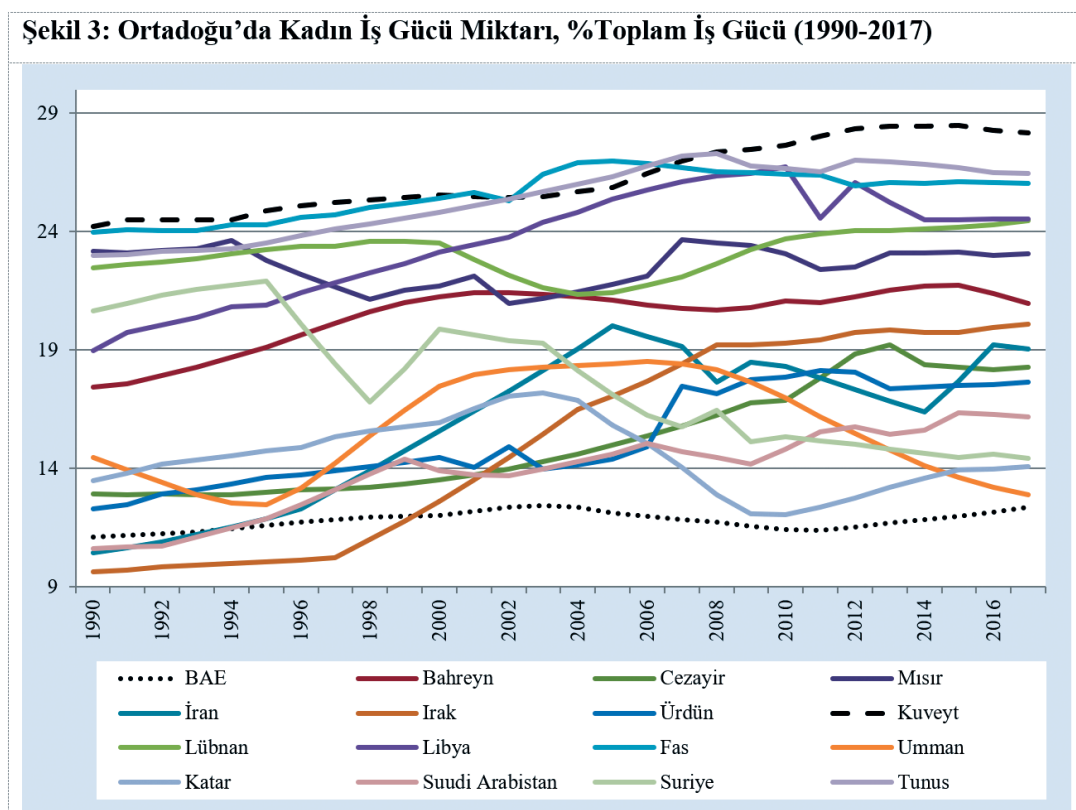

Kaynak: World Bank (2018), World Development Indicators, http://databank.worldbank.org/data/repor ts.aspx? source=World-Development-Indicators (Erişim: 22.09.2018)

Kadınların iş gücüne son derece düşük düzeyde katılım gösterdiği ve iş gücü piyasasının küçük bir bölümünü oluşturduğu Ortadoğu ve Kuzey Afrika ülkeleri özelinde bir değerlendirme yapılacak olur ise kadınların iş gücüne en yoğun şekilde katılım gösterdiği ve artış trendi bulunan ülkelerin \% 40-60’lar düzeyinde oranlara sahip olan Katar, Kuveyt, Bahreyn ve BAE gibi doğal kaynak zengini Körfez ülkeleri olduğu, ancak bu durumun kadınların toplam iş gücü büyüklüğüne daha yüksek oranda katılım göstermesine sebebiyet vermediği anlaşılmaktadır. Diğer ülkelerde ise katılım oranlarının \%10-30 düzeyinde ve çoğunlukla yatay bir eğilim izlediği, kadınların toplam iş gücü piyasası içerisindeki payı açısından da, katılım oranlarına benzer şekilde \%10-30 trendinde değişen ve genel olarak konjonktürel artışların/azalışların bulunduğu bir eğilimin olduğu müşahede edilmektedir (Murray \& Zhang-Zhang, 2018). 
Şekil 4: Ortadoğu'da Kadınların İş Gücüne Katılım Oranı, \% (1990-2017)

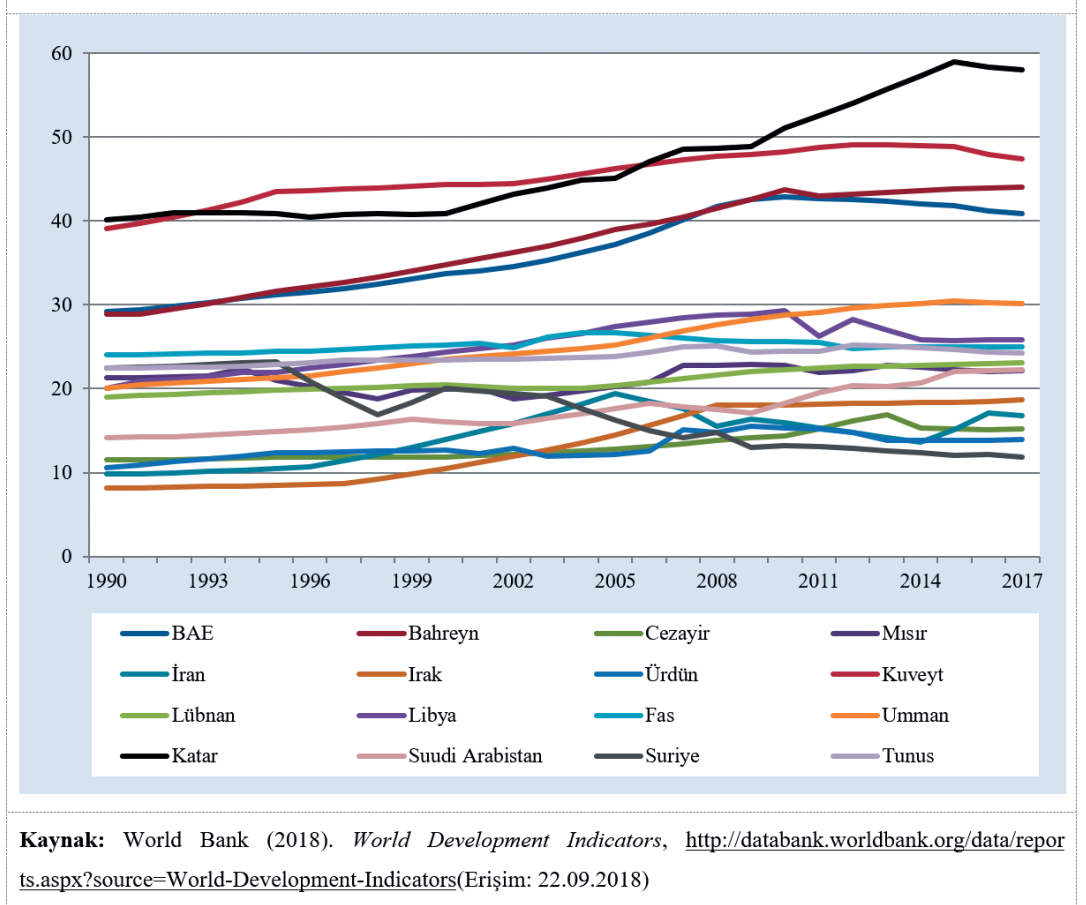

\section{Kadın İş Gücü ve İstihdamının Belirleyicileri: Literatür Taraması}

Bir üretim faktörü olarak emek, özellikle küreselleşme sürecinin yıkıcı tesirleri altında, çoğu kez serbest piyasa ekonomisinin kazanımlarından yeteri kadar istifade edememiştir. Bununla birlikte özellikle az gelişmiş ya da gelişmekte olan ülkelerde olmak üzere emeğin üretimden aldığı pay genel olarak yetersiz kalmış; hatta bilgi teknolojilerindeki hızlı dönüşümün istihsal süreçlerine hâkim kıldığı "emeksiz" üretim mantalitesi bağlamında çoğu defa üretim sürecinin dominant bir parçası olmaktan geri kalmıştır.

Genel olarak emek piyasasında yaşanan bu değişimler, yıllar içerisinde birçok sosyal, siyasal ve ekonomik engelleri bertaraf ederek ve yakın sayılacak bir süreçte "ücretli" olarak bu piyasaya katılan ve genel olarak erkek emeğinden farklı özellikler barındıran 
kadın emeğinin, iş gücü piyasasında yer alma şeklini, konumunu ve önemini belirgin ölçüde etkilemiştir. Bu bağlamda kadın emeği, gerek üretim faktörü bağlamında gerekse de üretim-büyüme/kalkınma ekonomisi çerçevesinde münhasıran araştırmaya konu ayrı bir alana ve ağırlığa sahip bulunmaktadır (Bkz. United Nations, 2015; World Economic Forum, 2018).

Kalkınma ile ilgili literatür incelendiğinde, özellikle 1970’li yıllardan önce kadınların toplumsal hayat içerisindeki rollerinin emek/iş gücü piyasasına katılımlarını ve bu durumun genel olarak ülkenin kalkınma süreçlerini ne yönde etkilediği hususlarının büyük ölçüde görmezden gelindiği, ancak bu yıllardan sonra konuya olan ilginin arttığı ve literatüre önemli çalışmaların² girdiği müşahede edilmektedir (Beneria \& Sen, 1981).

Beşeri sermayenin ekonomik büyüme ve kalkınmanın en önemli itici faktörlerinden olduğu bilinmektedir. Bu bağlamda genel olarak ülkelerin nüfusunun yarısını oluşturan kadınların, gelişmişlik seviyesi her ne olursa olsun çoğu ülkede, iş gücüne katılım düzeyleri düşük kaldığı gibi, niceliksel olarak toplam üretim miktarına yönelik katkıları daha da düşük oranlarda bulunmaktadır. Kuşkusuz bu durumun büyüme ve ekonomik refah üzerinde birçok olumsuz etkileri bulunmaktadır (Psacharopoulos \& Tzannatos, 1989; Günsoy \& Özsoy, 2012).

Zira özel bir üretim faktörü olarak değerlendirilebilecek kadın emeği, herhangi bir cinsiyet ayrımına muhatap olmadan -ki bu durum iş gücünün genel kabiliyetini arttıracak ve böylelikle ekonomik gelişmeyi de teşvik edecektir- iş gücüne daha yüksek oranda katılım gösterir ise öncelikle iş gücü arzı artacak ve üretim artışı dolayısıyla ekonomik büyüme hılanacaktır. Ekonomik büyümenin itici gücü olarak değerlendirilebilecek bu husus toplumsal ve siyasal alanda da kadınların katılım düzeyi ve temsil kabiliyetini arttıracak ve böylelikle sürdürülebilir ekonomik kalkınmayı/gelişmeyi de temin edebilecektir (Goldin, 1994; Fatima \& Sultana, 2009; Verick, 2014; Xu, 2015; Aytekin, 2017; Tutar \& Yetişen, 2009).

2 Bu çalışmalardan birisi için bkz. Ester Boserup (1970), Woman's Role in Economic Development, London: George Allen\&Unwin. 
Bununla birlikte, kadınların daha yüksek düzeyde iş gücüne katılım göstermeleri, ekonomik açıdan daha özgür bireyler olmalarına ve toplum içinde daha saygın bir konum elde etmelerine imkân sağlayabilecektir. Yine bu doğrultuda kadınların annelik görevlerini daha iyi yerine getirebildikleri bir sosyal ortamın varlığı, gelecek nesillerin de daha sağlıklı olarak şekillenmesinde önemli rol oynayacaktır (Duflo, 2012; Yıldırım \& Doğrul, 2008).

$\mathrm{Bu}$ açıklamalar ve literatürde yapılan çalışmalar çerçevesinde genel olarak iş gücüne katılım düzeyinin belirlenmesinde nüfus, yaş, cinsiyet, medeni durum, hane halkı büyüklüğü, değer yargıları, iş gücü piyasasına yönelik kurumsal düzenlemeler ${ }^{3}$, gelir ve ekonomik büyüklük gibi temel belirleyici faktörlerin ön plana çıktığı görülmektedir (Akgeyik, 2016; Yamak, Abdioğlu \& Mert, 2012).

Münhasıran kadınların iş gücüne katılımına yönelik çalışmalarda ise medeni durum, toplumsal cinsiyet algısı, eğitim durumu/ düzeyi, ücretsiz aile işçiliği, kayıt dışı kadın istihdamı, ücretler, doğurganlık, yaş, genel işsizlik düzeyi, eşlerin eğitim düzeyi, göç, ekonomik dönem/konjonktür, ekonominin sektörel kompozisyonu, hane halkı gelir seviyesi/düzeyi, GSYİH büyüklüğü, kentleşme, kültürel ve dinî değerler, muhafazakâr toplum yapısı ile istihdamı teşvik eden politik ve kanuni düzenlemeler ${ }^{4}$ gibi hususların temel belirleyici etmenler olarak tespit edildikleri anlaşılmaktadır (Mammen \& Paxson, 2000; Mehrotra \& Parida, 2017; Çatalbaş, 2015; Dayığlu \& Kırdar, 2010; Morikawa, 2015; Günsoy \& Özsoy, 2012; Uysal, Keskin \& Sertkaya, 2016; Tansel, 2014; Yıldırım \& Doğrul, 2008; Zeren \& Kılınç, 2017).

Bu noktada, kadın istihdamının belirleyicilerin ampirik olarak test edildiği çalışmalardan ve bu çalışmalarda elde edilen bulgulardan bahsetmek faydalı olacaktır. Nam (1991) Güney Kore'de (Seul)

3 Detaylı bilgi için bkz. F. D. Blau ve L. M. Kahn (1999), Institutions and Laws in the Labor Market, Handbook of Labor Economics 3 içinde (1399461).

4 Kadınların iş gücüne katılımını etkileyen politikalar hakkında önemli ve detaylı bilgiler için bkz. F. Jaumotte (2003), Female Labour Force Participation: Past Trends and Main Determinants in OECD Countries, OECD Economics Department Working Papers (No. 376). 
erkek egemen hanelerde yaşayan kadınların iş gücüne katılımının belirleyicilerini 1970 ve 1980'de iki noktada incelemiş, bu bağlamda kadınların eğitim düzeyinin, ailenin ekonomik durumunun/gelir seviyesinin, medeni durumunun ve çocuk sayısının (6 yaştan küçük) kadınların iş gücüne katılımını belirlediğini tespit etmiştir.

Jaumotte (2003) 1985-1999 döneminde 17 OECD ülkesinde kadınların iş gücüne katılımının belirleyicilerinin tespitine yönelik çalışması neticesinde, eğitim düzeyi, teşvik edici tarafsız vergi uygulamaları, çocuk bakımı sübvansiyonları, iş gücü piyasası koşulları ve kültürel tutumların, kadınların iş gücüne katılımının temel belirleyicileri olduğunu tespit etmiştir.

Özer \& Biçerli (2003/2004), 1988-2001 döneminde Türkiye'de kadınların iş gücüne katılımını etkileyen faktörleri, en küçük kareler regresyonu yöntemi ile araştırdıkları çalışmaları neticesinde; aktif kadın nüfusu içinde ev kadınlarının oranı, istihdam edilen kadın iş gücü içerisinde ücretsiz aile işçilerinin oranı ve $12+$ yaş nüfus içinde toplam emeklilerin oranı değişkenlerinin, kadınların iş gücüne katılımı üzerinde anlamlı etkileri olduğu sonucuna erişmişlerdir.

Robinson (2005) 1960-2000 dönemi için, Orta Doğu ve Kuzey Afrika ülkelerinde kadınların iş gücüne katılım oranlarını belirleyen faktörleri tespit etmeye yönelik olarak regresyon analizi yöntemi ile gerçekleştirdiği çalışma neticesinde, iş bu ülkelerde büyüme, okuryazarlık, kişi başına düşen gelir ve toplam doğurganlık oranlarının, kadınların iş gücüne katılım oranını arttırdığı, sonucuna ulaşmıştır.

Chamlou, Muzi \& Ahmed (2011) Orta Doğu ve Kuzey Afrika ülkeleri özelinde kadın iş gücü arzının belirleyicilerinin anlaşılmasına yönelik çalışmalarında, eğitimin ve sosyal normların rolünü dikkate almışlar ve bu bağlamda temsilci (Proxy) ülke olarak Amman'a (Ürdün) ait verileri kullanmışlardır. Çalışma ile yüksek öğrenimin iş gücüne katılım oranları üzerinde pozitif ve anlamlı bir etkiye sahip olduğu, bununla birlikte geleneksel sosyal normlar ile kadınların iş gücüne katılımı arasında negatif ve istatistiksel olarak anlamlı bir ilişki bulunduğu sonucuna erişmişlerdir. 
Ayvaz \& Kızılgöl (2012) yaptığı çalışmada, 2002-2008 döneminde Türkiye genelinde, kentsel ve kırsal alanlarda yaşayan evli ve bekâr kadınların iş gücüne katılımını etkileyen hususları logit model analizleri yöntemi ile araştırmış; bu bağlamda eğitim durumu artışlarının kadınların iş gücüne katılımı için en önemli faktör olduğu, bunun yanı sıra hane halkı geliri, çocuk sayısı, bağımlılık oranı, kadının yaşı ile oturulan konutun mülkiyeti gibi unsurların da kadınların iş gücüne katılımı üzerinde etkili olduğu sonucuna erişmiştir.

Thévenon (2013) 18 OECD ülkesi için 1980’lerin başından itibaren, iş gücü piyasasının ve kurumsal özelliklerin kadın iş gücüne katılımı ve tam zamanlı ve yarı zamanlı istihdam katılımı üzerindeki etkisini incelediği çalışmasında, eğitim düzeyinde ve hizmet sektörünün yarı zamanlı istihdam firsatlarındaki artışların kadınların iş gücüne katılımını arttırdığını vurgulamaktadır.

Kılıç \& Öztürk (2014) 2002-2008 döneminde Türkiye'de kadınların iş gücüne katılımının belirleyicilerini standart probit modeli ile tahmin ettikleri çalışmalarında ise özellikle eğitim olmak üzere, medeni durum, ekonomik kaynaklar, toplumsal cinsiyet algisı ve kentleşme gibi faktörlerin, kadınların iş gücüne katılımını belirleyen faktörler olduğu sonucuna ulaşmışlardır.

Sorsa vd. (2015) Hindistan'da kadınların iş gücüne katılımının belirleyicilerini değerlendirdikleri çalışmalarında, ülkedeki büyük bölgesel farklılıklar göz önünde bulundurularak analiz bölge ve kırsal ve kentsel alanlar arasında yürütülmüş bu bağlamda, diğer pek çok çalışmanın aksine eğitim durumu ve gelir düzeyi ile kadın iş gücü arasında negatif ilişki tespit etmiş, sosyal ve kültürel faktörlerin de kadının iş gücünü olumsuz etkilediğini belirlemişlerdir. Bunun yanı sıra, alt yapı, finansmana erişim, çalışma yasaları ve kırsal istihdam programlarının da diğer belirleyiciler olduğunu ifade etmişlerdir.

Hosney (2015), 2012 yılı için Mısır ve Almanya'da kadın iş gücüne katılımı etkileyen faktörleri probit modeli ile tahmin ettiği çalışmasında, daha yüksek eğitim düzeyinin Mısırlı kadınların iş gücü piyasasına katılma ihtimalini arttırdığını, her iki ülkede okul 
yılı ve yaş etkeninin pozitif bir etkisi bulunduğunu, bunun yanı sıra evli bir kadın olmak, kentsel alanlarda yaşamak ve çocuk sayısının ise kadın istihdamı üzerinde olumsuz etkilerinin bulunduğunu ortaya koymuştur.

Taşseven, Altaş \& Ün (2016) 1990 ve 2013 döneminde OECD ülkelerinde kadın istihdamının belirleyicilerini tespite yönelik çalışmaları neticesinde, işsizlik, kişi başına gayri safi yurt içi hâsılanın ve doğurganlık oranının kadın iş gücüne katılım oranını olumlu ve anlamlı bir şekilde etkilediği sonucuna erişmişlerdir.

Demirtaş \& Yayla (2017) ise1995-2012 yılları arasında, küresel entegrasyonun kadın istihdamı üzerindeki etkisini OECD ülkeleri ve gelişmekte olan ülkeler (toplam 113 ülke) için incelemişler ve bu bağlamda OECD ülkelerinde küreselleşme değişkenlerinin tamamının kadın istihdamı üzerinde pozitif, doğrudan yabancı yatırımlarının hem OECD ülkelerinde hem de gelişmekte olan ülkelerde kadın istihdamı üzerinde pozitif yönde etkiye, gelişmekte olan ülkelerde dışa açıklık oranı ve ithalat kadın istihdamını negatif etkiye, ekonomik ve sosyal küreselleşme endekslerinin ise herhangi bir etkiye sahip olmadığı sonucuna ulaşmışlardır.

\section{Ortadoğu'da Kadınların İş Gücüne Katılımı Üzerine Bir Uygulama}

Afrika, Avrupa ve Asya kıtalarının kesiştiği önemli bir noktada bulunan ve küresel doğal kaynak rezervlerinin büyük bir oranına ve önemli ticaret yollarına sahip olan Ortadoğu ve Kuzey Afrika bölgesi, ekonomik olarak doğal kaynak rantı merkezinde şekillenen yapıya, siyasi olarak ise baskıcı/otoriter rejimler tarafindan kurgulanan hibrit yapılara sahip bulunmaktadır. Çoğunlukla geleneksel yapıdan kaynaklanan ve kadının toplumsal rolünün daha çok aile içinde kurgulanması ile başlayan ve düşük eğitim, genç evlilik, yüksek doğurganlık, cinsiyet ayrımcılığı gibi kültürel pratikler, demografik ve kurumsal nedenler ve politik dinamikler ile pekişen hususlar dolayısıyla bölgede yaşayan kadınların statüsünde iş bu gelişmelere rağmen kayda değer bir ilerleme sağlanamadığı gibi daha önce de ifade edildiği üzere ekonomik hayata ve bunun bir 
parçası olarak iş gücü piyasasına son derece düşük düzeyde katılım göstermişlerdir (Moghadam, 1990).

Bu çalışma ile 1990-2016 döneminde kadın istihdamının dünya genelinde en düşük düzeyde olduğu Ortadoğu ve Kuzey Afrika'da, kadınların iş gücüne katılımının belirleyicileri fark ve sistem GMM yöntemleri kullanılarak ortaya konulmak istenilmiş; bu çerçevede diğer çalışmalardan farklı olacak şekilde ve literatüre katkı sağlayacak şekilde, toplumların meydana getirdiği yazılı kurallar/düzenlemeler ile tarihî süreklilik içerisinde devam etmekte olan örfî kurallar/enformel alışkanlıklarının tamamını belirten kurumsal yapının da kadın istihdamı üzerindeki etkileri değerlendirmeye konu edilmiştir.

\subsection{Veri seti ve yöntem}

Araştırma modelinde yer alan değişkenler için kullanılan kısaltmalara, verilerin elde edildikleri kaynaklara ve kapsadığ dönem ile ölçüm değerlerine ilişkin bilgiler Tablo 1'de sunulmuştur.

Tablo 1: Değişkenlere Ait Bilgiler

\begin{tabular}{|c|c|c|c|}
\hline $\begin{array}{l}\text { Değişkenin } \\
\text { Adı }\end{array}$ & $\begin{array}{l}\text { Değişkenin } \\
\text { Kısaltması }\end{array}$ & $\begin{array}{l}\text { Değişkenin } \\
\text { Kaynağı }\end{array}$ & $\begin{array}{l}\text { Değere ilişkin } \\
\text { Açıklama }\end{array}$ \\
\hline Kadınların İş Gücüne Katılım Oranı & Ifp & $\begin{array}{l}\text { Dünya Kalkınma Göstergeleri } \\
\text { (WDI) }\end{array}$ & $\%$ \\
\hline Politik Özgürlükler & pol & $\begin{array}{l}\text { Özgürlük Evi } \\
\text { (Freedom House) }\end{array}$ & $\begin{array}{l}\text { En Yüksek=1 } \\
\text { En Düşük=7 }\end{array}$ \\
\hline Sivil Özgürlükler & civ & $\begin{array}{l}\text { Özgürlük Evi } \\
\text { (Freedom House) }\end{array}$ & $\begin{array}{l}\text { En Yüksek=1 } \\
\text { En Düşük=7 }\end{array}$ \\
\hline $\begin{array}{l}\text { Kişi Başına Düşen GSYiH } \\
\text { (2000 Yılı Sabit Fiyatlarla) }\end{array}$ & gdp & $\begin{array}{l}\text { Dünya Kalkınma Göstergeleri } \\
\text { (WDI) }\end{array}$ & US\$ \\
\hline $\begin{array}{l}\text { Dışa Açıklık Oranı } \\
\text { (Toplam Dış Ticaret/GSYiH) }\end{array}$ & $\operatorname{trd}$ & $\begin{array}{l}\text { Dünya Kalkınma Göstergeleri } \\
\text { (WDI) }\end{array}$ & $\%$ \\
\hline Kentleşme Oranı & urb & $\begin{array}{l}\text { Dünya Kalkınma Göstergeleri } \\
\text { (WDI) }\end{array}$ & $\%$ \\
\hline $\begin{array}{l}\text { Doğurganlık Oranı } \\
\text { (Kadın Başına) }\end{array}$ & fer & $\begin{array}{l}\text { Dünya Kalkınma Göstergeleri } \\
\text { (WDI) }\end{array}$ & Adet \\
\hline $\begin{array}{l}\text { Okullaşma Oranı } \\
\text { (Lise Düzeyinde, Kadın) }\end{array}$ & ens & $\begin{array}{l}\text { Dünya Kalkınma Göstergeleri } \\
\text { (WDI) }\end{array}$ & $\%$ \\
\hline Ücretsiz Aile İşçiliği & fam & $\begin{array}{l}\text { Dünya Kalkınma Göstergeleri } \\
\text { (WDI) }\end{array}$ & $\%$ \\
\hline
\end{tabular}


Analizde kullanılan değişkenlere ilişkin tanımlayıcı istatistikler Tablo 2'de sunulmuştur.

Tablo 2: Tanımlayıcı İstatistikler

\begin{tabular}{|c|c|c|c|c|c|}
\hline Değișken & Göz. Say. & Ort. & St. Dev. & Min. & Maks. \\
\hline Ifp & 162 & 25.29 & 12.10 & 6.13 & 58.22 \\
\hline pol & 162 & 5.84 & 0.92 & 1 & 7 \\
\hline civ & 162 & 5.46 & 0.90 & 3 & 7 \\
\hline gdp & 159 & 10301.87 & 14741.65 & 314.86 & 87605.92 \\
\hline trd & 149 & 83.90 & 33.92 & 0.22 & 196.6 \\
\hline urb & 162 & 70.97 & 18.02 & 21.49 & 99.24 \\
\hline fer & 162 & 3.37 & 1.26 & 1.6 & 8.45 \\
\hline ens & 132 & 71.13 & 26.43 & 8.14 & 108.68 \\
\hline fam & 162 & 13.26 & 16.60 & 0 & 58.8 \\
\hline
\end{tabular}

\subsection{Model ve hipotez}

Çalışmanın literatür kısmında detaylarından bahsedildiği üzere bu alandaki çalışmalar incelendiğinde, genel olarak kadın istihdamını etkileyen faktörlerin eğitim, medeni durum, yaş, doğurganlık oranı ve yerleşim yeri gibi hususları barındıran sosyo-demografik unsurlar ile ekonomik büyüme ve enflasyon gibi parametrelerin yanı sıra kısmi çalışmalarda küresel entegrasyon değişkenlerini de içine alan ekonomik belirleyiciler olduğu görülmüş; bunun yanında, kayıt dışı istihdam, ücret ayrımcılığı, cinsiyet adaletsizliği gibi faktörlerin de çalışmalarda yer aldığı müşahede edilmiştir (Demirtaş \& Yayla, 2017).

Bu çalışmada Kadınların İş Gücüne Katılım Oranı (lfp) bağımlı değişken olarak modelde yer almakta olup, literatüre özgün bir katkı sunması bakımından, insanlar tarafından oluşturulan ve aralarındaki ilişkileri şekillendiren genel kabul görmüş alışkanlık biçimleri olan kurumların meydana getirdiği kurumsal yapıya ilişkin göstergelerin kadınların iş gücüne katılım oranı üzerindeki belirleyici etkisi Politik Özgürlükler (pol) ve Sivil Özgürlükler (civ) başlıkları altında incelenmiştir. Bu bağlamda, kurumsal yapıyı 
temsilen çalışmanın amacı ve hipotezleri ile uyum göstermekte olup Freedom House $^{5}$ tarafindan üretilen ve ülkelerin genel özgürlük düzeylerini temsil eden Dünya Özgürlük Anketi verileri tercih edilmiştir (North, 2001; Artan \& Hayaloğlu, 2014).

Diğer yandan genel olarak kadın iş gücünün belirleyicileri olarak literatürdeki araştırmalara dahil edilen parametrelerden Kişi Başına Düşen GSYH (gdp) ve Dışa Açıklık Oranı (trd) değişkenleri ekonomik belirleyiciler; Kentleşme Oranı (urb), Doğurganlık Oranı (fer), Okullaşma Oranı (ens) ile Ücretsiz Aile İşçiliği (fam) ise sosyodemografik veriler olarak modele dahil edilmiştir.

Bu çerçevede, Fark ve Sistem GMM ile tahmin edilecek genel model aşağıdaki şekilde oluşturulmuştur;

$$
\begin{aligned}
& \text { yit }=\text { a yi,t }-1+\text { x'itb }+ \text { eit } \\
& \varepsilon i t=\mu \mathrm{i}+\text { vit } \\
& \mathrm{E}(\mu \mathrm{i})=\mathrm{E}(\text { vit })=\mathrm{E}(\mu \mathrm{ivit})=0
\end{aligned}
$$

Hata terimi عit'nin sabit etki $\mu \mathrm{I}$ ve idiyosikratik şok vit olmak üzere iki ortogonal bileşeni vardır (Rodman, 2009);

$$
\begin{aligned}
& \Delta y i t=(a-1) \Delta y i, t-1+\Delta x ' i t+\Delta v i t \\
& \mathrm{E}[\Delta \text { wit } \mu \mathrm{i}]=0
\end{aligned}
$$

Kurumsal belirleyiciler için indirgenmiş form denklemi;

$$
\begin{aligned}
& \text { lfpit }=\alpha \text { lfpi,t- } 1+81 \text { polit }+82 \text { civit }+ \text { eit } \\
& \varepsilon \text { it }=\mu \mathrm{i}+\mathrm{it} \\
& \mathrm{E}(\mu \mathrm{i})=\mathrm{E}(\text { vit })=\mathrm{E}(\mu \mathrm{ivit})=0 \\
& \Delta \mathrm{lfpit}=\delta \Delta \text { lfpi,t- } 1+\varphi \Delta \text { polit }+\Lambda \Delta \text { civit }+\Delta \text { vit } \\
& \mathrm{E}[\Delta \text { wit } \mu \mathrm{i}]=0
\end{aligned}
$$

5 Freedom House endeksinde ekonomik özgürlükler, politik haklar ve bireysel özgürlükler olmak üzere iki kategori çerçevesinde ele alınmaktadır. Bu çerçevede her iki kategoride de (1) ile (7) arasında puanlandırılmaktadır. (1) en yüksek özgürlük derecesini nitelendirirken, (7) ise en düşük özgürlük seviyesini göstermektedir. Sonuçta ülkeler özgür, kısmen özgür veya özgür değil şeklinde sınıflandırılmaktadır. Detaylı bilgi için bkz. https://freedomhouse.org/report/methodologyfreedomworld-2018 (Erişim: 24.08.2018) 
Ekonomik belirleyiciler için indirgenmiş form denklemi;

$$
\begin{aligned}
& \text { lfpit }=\alpha \text { lfpi,t }-1+B 1 \text { gdpit }+82 \text { trdit }+ \text { cit } \\
& \varepsilon i t=\mu \mathrm{i}+\text { it } \\
& \mathrm{E}(\mu \mathrm{i})=\mathrm{E}(\text { vit })=\mathrm{E}(\mu \mathrm{ivit})=0 \\
& \Delta \text { lfpit }=\delta \Delta \text { lfpi,t- } 1+\varphi \Delta \text { gdpit }+\lambda \Delta \text { trdit }+\Delta \text { vit } \\
& \mathrm{E}[\Delta \text { wit } \mu \mathrm{i}]=0
\end{aligned}
$$

Sosyo-demografik belirleyiciler için indirgenmiş form denklemi;

lfpit $=a$ lfpi,t $-1+B 1$ urbit $+B 2$ ferit $+B 3$ ensit $+B 4$ famit + cit

cit $=\mu \mathrm{i}+\mathrm{it}$

$\mathrm{E}(\mu \mathrm{i})=\mathrm{E}($ vit $)=\mathrm{E}(\mu \mathrm{ivit})=0$

$\Delta$ lfpit $=\delta \Delta$ lfpi,t $-1+\varphi \Delta$ urbit $+\lambda \Delta$ ferit $+\varphi$ enst $+\Psi \Delta$ famit $+\Delta$ vit (3.4)

$\mathrm{E}[\Delta$ witui $]=0$

$\operatorname{lfp}_{\text {it }}$ i ülkesi için t zamanında ve $\operatorname{lfp}_{\mathrm{i}, \mathrm{t}-1}$ i ülkesi için t-1 zamanında Kadınların İ̧̧ Gücüne Katılım Oranı değiş̧kenini; pol $_{\text {it }}$ ve $_{\text {civ }}$ it, kurumsal belirleyicileri sırasıyla, i ülkesi için t zamanında Politik

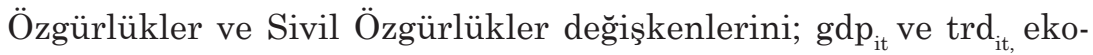
nomik belirleyicileri sırasıyla, i ülkesi için t zamanında Kişi Başına Düşen GSYH ve Dışa Açıklık Oranı değişkenlerini; urb $_{\mathrm{it}}, \mathrm{fer}_{\mathrm{it}}, \mathrm{ens}_{\mathrm{it}}$ ve fam $_{\text {it, }}$ sosyo-demografik belirleyicileri sırasıyla, i ülkesi için t zamanında Kentleşme Oranı, Doğurganlık Oranı, Okullaşma Oranı ve Ücretsiz Aile İşçiliği değişkenlerini ölçmektedir.

Konuya dair literatür bağlamında çalışmanın hipotezleri şu şekildedir:

Hipotez 1: Politik özgürlüklerin (pol) kadınların iş gücüne katılımı (lfp) üzerinde pozitif ve anlamlı etkisi bulunmaktadır.

Hipotez 2: Sivil özgürlüklerin (civ) kadınların iş gücüne katılımı (lfp) üzerinde pozitif ve anlamlı etkisi bulunmaktadır.

Hipotez 3: Kişi başına düşen GSYİH miktarının (gdp) kadınların iş gücüne katılımı (lfp) üzerinde pozitif ve anlamlı etkisi bulunmaktadır. 
Hipotez 4: Dışa açıklık oranının (trd) kadınların iş gücüne katılımı (lfp) üzerinde pozitif ve anlamlı etkisi bulunmaktadır.

Hipotez 5: Kentleşme oranının (urb) kadınların iş gücüne katılımı (lfp) üzerinde pozitif ve anlamlı etkisi bulunmaktadır.

Hipotez 6: Doğurganlık oranının (fer) kadınların iş gücüne katılımı (lfp) üzerinde negatif ve anlamlı etkisi bulunmaktadır.

Hipotez 7: Okullaşma oranının (ens) kadınların iş gücüne katılımı (lfp) üzerinde pozitif ve anlamlı etkisi bulunmaktadır.

Hipotez 8: Ücretsiz aile işçiliğinin (fam) kadınların iş gücüne katılımı (lfp) üzerinde pozitif ve anlamlı etkisi bulunmaktadır.

\subsection{Bulguların değerlendirilmesi}

Kurumsal değişkenlere ilişkin ampirik bulgular genel olarak değerlendirildiğinde 1 nolu hipotezin aksine politik özgürlüklerin kadınların iş gücüne katılımı üzerinde negatif ve anlamlı etkisinin olduğu; sivil özgürlüklerin ise 2 nolu hipotezle uyumlu olacak şekilde kadınların iş gücüne katılımı üzerinde pozitif ve anlamlı etkisinin bulunduğu anlaşılmıştır.

Kontrol değişkenlerinden kişi başına düşen gayri safi yurt içi hâsıla, dışa açıklık oranı ve kentleşme oranındaki artışın Hipotez 3, Hipotez 4 ve Hipotez 5 ile uyumlu şekilde kadınların iş gücüne katılım oranı üzerinde pozitif ve anlamlı etkisinin olduğu; doğurganlık oranı ile okullaşma oranındaki artışın kadınların iş gücüne katılım oranı üzerinde negatif ve anlamlı etkisinin bulunduğu; öte yandan ücretsiz aile iş̧̧iliği ile kadınların iş gücüne katılım oranı arasında ise anlamlı bir ilişki olmadığı tespit edilmiştir. 
Tablo 3: Sistem GMM Sonuçları

\begin{tabular}{|c|c|c|c|}
\hline Değişkenler & & Sonuçlar & \\
\hline Bağımlı Değişken: Ifp & 1-Fark GMM & 2-Sistem GMM & 3-Sistem GMM \\
\hline $\begin{array}{l}\text { 1.Ifp (Kadınların İş Gücü } \\
\text { Katılımının 1. Gecikmesi) }\end{array}$ & $\begin{array}{c}0.688^{* * *} \\
(0.155)\end{array}$ & $\begin{array}{c}0.962^{* * *} \\
(0.034)\end{array}$ & $\begin{array}{c}0.902^{* * *} \\
(0.108)\end{array}$ \\
\hline pol(Politik Özgürlükler) ${ }^{1}$ & $\begin{array}{c}0.633^{* * *} \\
(0.207)\end{array}$ & & \\
\hline civ(Sivil Özgürlükler) ${ }^{1}$ & $\begin{array}{l}-2.223^{* *} \\
(1.004)\end{array}$ & & \\
\hline $\begin{array}{l}\text { gdp(Kişi Başına Düşen } \\
\text { GSYİH) }\end{array}$ & & $\begin{array}{l}0.00005^{*} \\
(0.00002)\end{array}$ & \\
\hline trd (Dış̧a Açıklık Oranı) & & $\begin{array}{l}0.012^{* *} \\
(0.005)\end{array}$ & \\
\hline urb(Kentleşme Oranı) & & & $\begin{array}{l}0.152^{*} \\
(0.082)\end{array}$ \\
\hline fer(Doğurganlık Oranı) & & & $\begin{array}{l}-1.413^{*} \\
(0.676)\end{array}$ \\
\hline ens (Okullaşma Oranı) & & & $\begin{array}{l}-0.051^{*} \\
(0.028)\end{array}$ \\
\hline $\begin{array}{l}\text { fam (Ücretsiz Aile } \\
\text { İşçiliği) }\end{array}$ & & & $\begin{array}{c}0.022 \\
(0.029)\end{array}$ \\
\hline Prob $>F$ & 0.000 & 0.000 & 0.000 \\
\hline Ülkeler & 18 & 18 & 18 \\
\hline Enstrümanlar & 12 & 12 & 26 \\
\hline Hansen & 0.537 & 0.364 & 0.999 \\
\hline$A R(3)$ & 0.454 & 0.870 & 0.318 \\
\hline $\begin{array}{l}{ }^{1} \text { Politik özgürlükler (pol) ve } \\
\text { edildiği endeks (1=En Yüks } \\
\text { anlamlılık katsayıları ters o } \\
\text { Not: Parantez içindeki değ } \\
5 \text { ve \% } 10 \text { önem seviyelerir } \\
\text { ikincil fark kalanları içinde } \\
\text { özdeşleştirme Hansen test } \\
\text { Tüm değişkenler içsel olara } \\
\text { korelasyon testine göre en }\end{array}$ & $\begin{array}{l}\text { vil özgürlükler ( } \\
\text { Skor, } 7=\text { En Düşi } \\
\text { imalıdır. } \\
\text { ar robust standa } \\
\text { östermektedir. } \\
\text { incü derece ser } \\
\text { m enstrümanla } \\
\text { lınmıştır. İçsel c } \\
\text { üman edilmiştir }\end{array}$ & $\begin{array}{l}\text { leğişkenlerine ait } \\
\text { or) ters çalıştığınd } \\
\text { talardır.***,**v } \\
\text { ) seri korelasyon } \\
\text { elasyonun varlığın } \\
\text { eçerli olduğu hipc } \\
\text { kenlerin uygun ge }\end{array}$ & $\begin{array}{l}\text { ilerin temin } \\
\text { sonuçların } \\
\text { sırasıyla \% 1, \% } \\
\text { hipotezi altında } \\
\text { st eder. Aşırı } \\
\text { i altında yapılır. } \\
\text { meleri AR(3) seri }\end{array}$ \\
\hline
\end{tabular}

Demokratik temsil mekanizmalarının geliştiği ülkelerde politik hakların elde edilmesiyle bağlantılı olarak kadınların iş gücüne katılımını teşvik edecek kurumsal düzenlemeler uygulama imkânı bulduğundan, politik haklar ile kadınların iş gücüne katılım oranı 
arasında pozitif bir ilişkinin varlığından bahsedilmektedir ( $\mathrm{Lv} \&$ Yang, 2018; Iversen \& Rosenbluth, 2008). Oysaki Ortadoğu ve Kuzey Afrika ülkelerinde her ne kadar demokratik temsile dair bir kısım iyileşmeler gözlemlenmekteyse de, toplumsal cinsiyet temelli iş bölümüne ilişkin muhafazakâr değerlerin toplumsal hayata ve sosyal politika ortamına hâkim olması, çalışma hayatının kadına dair pozitif ayrımcılık içeren ve onu çalışma hayatında desteklemek üzerine kurgulanan politik bir alan haline dönüşmesine engel olmaktadır. Bununla birlikte bölge ekonomilerinin rantiyer ilişki döngüsü etrafinda şekillenmesi, sosyal güvenlik ve gelir problemi olmayan yüksek hayat standardına sahip kadınların istihdama katılmak yönünde gönüllü olmaması ve sadece politik temsil ve yaşam konforuna dair sınırlı taleplerinin bulunması gibi hususlar da kadın istihdamını kısıtlayan özellikler olarak zikredilmektedir. Açıklanan bütün bu sebepler Ortadoğu ve Kuzey Afrika'da politik özgürlüklerin (pol) kadınların iş gücüne katılımı (lfp) üzerindeki negatif etkisinin anlamlandırılmasını kolaylaştırmaktadır.

Bireyselleşme, şahsi hürriyetler, ifade ve örgütlenme haklarını kapsayan sivil özgürlüklerin gelişmesi ve genişlemesi ile birlikte kadınların toplumsal yaşama katılımları artacağı cihetle iş gücüne katılım talebinin de yükselmesi beklenmektedir. Bu bağlamda, her ne kadar Ortadoğu ve Kuzey Afrika ülkelerinde sivil özgürlükler ve kadınların iş gücüne katılım oranına dair belirgin iyileşmeler gözlemlenmemekteyse de ekonomik yapıdaki kısmi dönüşüm ile iş bulma özgürlügü gibi çeşitli toplumsal hürriyetlerin genişlemesinin kadın istihdamı üzerinde pozitif ve anlamlı etkiler ortaya koyduğu anlaşılmaktadır.

Ekonomik refahın en temel göstergesi olan kişi başına düşen gayri safi yurt içi hâsıla miktarı, küreselleşme sürecine entegrasyonu açıklayan dışa açıklık oranı ve modern yaşamı temsil eden kentleşme oranındaki artışın, ilgili hipotezlerde ifade edildiği şekliyle kadınların iş gücüne katılım oranı üzerinde pozitif ve anlamlı etkisinin bulunduğu ortaya konulmuştur. Benzer şekilde kadının toplumsal hayata katılımının aksine bir trende sahip olan doğurganlık oranı ile kadın istihdamı arasında da negatif ve anlamlı ilişkinin bulunduğu görülmektedir. 
Diğer taraftan okullaşma oranı ile kadın istihdamı arasındaki ilişki, ilgili ülkenin kalkınma düzeyi ile bağlantılı olarak gelir ve ikame etkileri üzerinden açıklanmaktadır. Gelir etkisi, aile gelirindeki artışın kadının emek arzı üzerindeki olası olumsuz etkisini; ikame etkisi ise kalkınmanın daha ileri aşamaları ile birlikte artan ücretlerin kadının emek arzı üzerindeki olumlu etkisini ifade etmektedir. $\mathrm{Bu}$ doğrultuda, bir kısmı yüksek gelirli ülkelerden oluşmaktaysa da, genel olarak düşük kalkınma düzeyinde bulunan Ortadoğu ve Kuzey Afrika bölgesinde gelir etkisinin ikame etkisini bastırması neticesinde okullaşma oranı ile kadınların iş gücüne katılım oranı üzerinde negatif ve anlamlı bir ilişki bulunduğu anlaşılmaktadır.

Nihayet, ücretsiz aile işçiliği (fam) ile kadınların iş gücüne katılımı (lfp) arasında anlamlı bir ilişki bulunmadığı görülmüştür. Literatür incelendiğinde ücretsiz aile işçiliği ile kadın istihdamı arasındaki ilişki genel olarak üretimin sektörel (tarım, sanayi, hizmetler) yapısındaki dönüşüm üzerinden açıklanmakta ve tarımsal üretimdeki modernleşme ile birlikte kadın istihdamının değişikliğe uğradığı ifade edilmektedir. Oysaki Ortadoğu ve Kuzey Afrika ülkelerinin üretim yapısının erkek iş gücüne dayalı olan sanayi sektöründe yoğunlaşması ve tarım sektörünün GSYİH içerisindeki payının görece düşük olması sebepleriyle Hipotez 8'de yer alan değişkenler arasında anlamlı bir ilişki bulunmadığı değerlendirilmektedir.

\section{Sonuç ve Öneri}

Nüfusunun yaklaşık yüzde 65'inin otuz yaşın altında olduğu ve kadın istihdamının dünya genelinde en düşük düzeyde bulunduğu Ortadoğu ve Kuzey Afrika ülkelerinde, küreselleşme çağında mevcut ekonomik gerçeklerle uyumlu olmayan aile yapılarının muhafaza edilmesi ile kadınların sosyo-ekonomik rollerine ilişkin tutumların/kültürel normların büyük ölçüde değişmemesi nedeniyle kadınların istihdamdan ve ekonomik hayattan uzak kaldıkları görülmektedir.

Kadınların ekonomik hayattan uzak kalmaları hususu ise bir yandan ekonominin potansiyel büyüklüğüne erişmesini 
engellemekte, diğer yandan da toplumsal yapının daha kapsayıcı bir temelde gelişmesine engel olmaktadır. Ancak bilinmektedir ki, kadınların istihdama daha yüksek oranda katılım göstermeleri münhasıran ekonomik büyümenin temin edilebilmesi için yeterli değildir. Bu noktada, kadınlara "dost” olan sektörlerde büyümeyi teşvik eden politikalar kritik öneme sahiptir. Bu bağlamda, büyümenin temel itici gücü konumunda olan ve çoğunlukla daha yüksek beceriye sahip iş gücünün istihdam imkânı bulduğu hizmet sektöründe kadın istihdamını teşvik edecek ve kadınların iş gücüne katılmaları önünde engel teşkil eden sosyal ve kültürel kısıtlamaları bertaraf edecek politikaların öncüllenmesi önem arz etmektedir (Lahoti ve Swaminathan, 2015). Zira Ortadoğu ve Kuzey Afrika bölgesinde kadınların ekonomik aktiviteye katılımı ve bunun meydana getirdiği pek çok sosyal faydanın, kurumsal yapıda, toplumsal cinsiyete dayalı tutumlarda ve üretimin yapısında önemli bir değişiklik olmadan tam olarak gerçekleşmeyeceği ortadadır.

$\mathrm{Bu}$ bağlamda, Ortadoğu ve Kuzey Afrika ülkelerinde kadın istihdamının arttırılması vasıtasıyla ekonomik büyümenin, beşeri kalkınmanın ve iktisadi çeşitlenmenin sağlanabilmesi için, UN Women Strategic Plan 2018-2021 raporunda yer alan hususlar da göz önünde bulundurulmak kaydıyla, kadınların iş gücü piyasalarına daha esnek şekilde katılabilmelerini teşvik eden normatif çerçevenin güçlendirilmesi, gelir güvenliği ile insana yakışır iş koşullarına sahip olmaları yönünde politikaların geliştirilmesi önem arz etmektedir.

Bu perspektifte Ortadoğu ve Kuzey Afrika'da, kadınların ekonomik hayata daha yüksek katılımları ile ekonomik olarak; uzun dönemde doğal kaynağa bağımlı ekonomik yapı çeşitlendirilebilecek, ekonomik büyüme/kalkınma/gelişme sağlanabilecek, diğer yandan gelir dağılımda adalet temin edilebilecektir. Bunun yanı sıra, sosyal ve toplumsal hayata ilişkin olarak ise 2010 Aralık ayı sonrası başlayan ve tüm bölgeyi etkisi altına alan Arap İsyanları sürecinin bölgede yarattığı yüksek tansiyonun azaltılması ile bölgede istikrarın temin edilebilmesi noktasında önemli sonuçlar elde edilebilecektir. 


\section{Kaynakça}

Akgeyik, T. (2016). Türkiye'de Kadınların İşgücü Piyasasına Katılımını Etkileyen Faktörler: TÜİK Verileri Üzerine Bir Analiz. Sosyal Siyaset Konferansları 70(1): 30-53.

Artan S. \& Hayaloğlu, P. (2014). Kurumsal Yapı ve İktisadi Yapı İlişkisi: Türkiye Örneği. Sosyo Ekonomi, (2014-2): 347-366.

Aytekin, B. (2017). Türkiye'de Kadın Emeğinin Etkinlik Sorunu ve Makroekonomik Etki Kanalları. Sayıştay Dergisi (107): 153-169.

Ayvaz Kızılgöz, Ö. (2012). Kadınların İşücüne Katılımının Belirleyicileri: Ekonometrik Bir Analiz. Doğus Üniversitesi Dergisi, 13(1): 88-101.

Beneria L.\& Sen, G. (1981). Development and Sexual Division of Labor. Journal of Women in Culture and Society, 7(2):279-298.

Buğra, A. (2010). Toplumsal Cinsiyet, İşgücü Piyasaları ve Refah Rejimleri: Türkiye'de Kadın İstihdamı. Tübitak Proje (No. 108K524).

Chamlou, S., Muzi, S \& Ahmed, H. (2011). Understanding the Determinants of Female Labor Force Participation in the Middle East and North Africa Region: The Role of Education and Social Norms in Amman. Alma Laurea Working Papers (No. 31).

Çatalbaş, G. K. (2015). Kadınların İşgücüne Katılımını Belirleyen Faktörlerin Belirlenmesi: Panel Veri Yaklaşımı. Kafkas Üniversitesi İktisadi ve İdari Bilimler Fakültesi Dergisi, 6(10): 249-280.

Çetin, T. (2012). Yeni Kurumsal İktisat. Sosyoloji Konferanslarl (45): 43-73.

Dayığlu, M.\& Kırdar, M. G. (2010). Türkiye'de Kadınların İşgücüne Katılımında Belirleyici Etkenler ve Eğilimler. Ankara: DPT ve Dünya Bankası Refah ve Sosyal Politika Analitik Çalışma Programı Raporu, No:5.

Demirtaş, G. \& Yayla, N. (2017). Küresel Entegrasyonun Kadın İstihdamı Üzerine Etkisi: Ampirik Bir İnceleme. Yaşar Üniversitesi Dergisi, 12 (48):339-349.

Duflo, E. (2012). Women Empowerment and Economic Development. Journal of EconomicLiterature, 50(4): 1051-1079.

Fatima, A. \& Sultana, H. (2009). Tracingoutthe U-shape Relationship Between Female Labor Force Participation Rate and Economic Development for Pakistan. International Journal of Social Economics, 36 (1/2):182-198.

Fischer, J. A. V. (2013). Globalization, Female Employment, and Regional Differences in OECD Countries. MPRA WorkingPaper (No. 45756).

Freedom House (2018). Freedom in the World Comparative and Historical Data: Country and Territory Ratings and Statuses, 1973-2018. https:// 
freedomhouse.org/content/freedom-world-data-and-resources(Erişim: 22.09.2018)

Gaddis, I \& Klasen, S. (2014). Economic Development, Structural Change, and Women's Labor Force Participation. Journal of Population Economics (27): 639-681.

Giddens, A. (2018). Sosyoloji - Kısa Fakat Eleştirel Bir Giriş (7. Baskı). Çev: Ü. Y. Battal, Ankara: Siyasal Kitabevi.

Goldin, C. (1994). The U-Shaped Female Labor Force Function in Economic Development and History. NBER Working Paper (No. 4707).

Günsoy, G. \& Özsoy, C. (2012). Türkiye'de Kadın İşgücü, Eğitim ve Büyüme İlişkisinin VAR Analizi. Finans Politik \& Ekonomik Yorumlar, 49 (568): 23-42.

Hosney, S. H. (2015). Factors Influencing Female Labor Force Participation in Egypt and Germany: A Comperative Study. SOEP papers on Multidisciplinary Panel Data Research (No. 286).

Iversen, T. \& Rosenbluth, F. (2008). Work and Power: The Connection Between Female LaborForec Participation and Female Political Representaation. Annual Review of Political Sciences (11): 479-495.

Jaumotte, F. (2003). Female Labour Force Participation: Past Trends and Main Determinants in OECD Countries. OECD Economics Department Working Papers (No. 376).

Karagül, M. (2014). Kalkınma Sürecinde Üretim Faktörlerinin Yeniden Tanımlanması. Leges Ekonomik ve Hukuk Araştırmaları Dergisi, 1(1): $1-11$.

Kılıç, D.\& Öztürk, S. (2014). Türkiye'de Kadınların İşgücüne Katılımı Önündeki Engeller ve Çözüm Yolları: Bir Ampirik Uygulama. Amme İdaresi Dergisi, 47(1): 107-30.

Kılınç, N. Ş. (2015). Küresel Eğilimler Çerçevesinde Kadın İstihdamı. Uluslararası Emek ve Toplum Dergisi, 4(9): 120-135.

Kottis, A. P. (1990). Shifts over Time and Regional Variation in Women's Labor Force Participation Rates in a Developing Economy. Journal of Development Economics (33): 117-132.

Küçükkalay, A. M. (2016). Dünya İktisat Tarihi (2. Baskı). İstanbul: Beta Yayınları.

Lahoti, R. ve Swaminathan, H. (2013). Economic Development and Female Labor Force Participation in India. Feminist Economics, 22(2): 168195.

Lv, Z. \& Yang, R. (2018). Does Women's Participation in Politics Increase Female Labor Participation? Evidence from Panel Data Analysis. EconomicsLetters (170): 35-38. 
Mehrotra, S. \& Parida, J. K. (2017). Why is the Labour Force Participation of Women Declining in India?. World Development (98): 360-380.

Mammen, K. \& Paxson, C. (2000). Women's Work and Economic Development. The Journal of American Perspective, 14(4):141-164.

Moghadam, V. M. (1990). Democracy and Women's Rights: Reflection on the Middle East and North Africa. International Seminar Comperative Studies on Family Democratization and Socio-Politics (24-26 September 2008), Buenos Aires.

Moghadam V. M. (2011). Ortadoğu'da Kadınların Modernleşmesi. Youssef M. Choueiri (ed.), Ortadoğu Tarihi - Dini, Siyasi, Kültürel ve Ekonomik Perspektiften İçinde (505-527), İstanbul: İnkilap Yayınları.

Morikawa, Y. (2015). The Opportunities and Challenges for Female Labor Force Participation in Morocco. Global Economy and Development Working Paper (No. 86).

Murray, J. Y. \& Zhang-Zhang, Y. (2018). Insights on Women's Labor Participation in Gul fCooperation Council Countries. Business Horizons, 61(5): 711-720.

Nam, S. (2001). Determinants of Female Labor Force Participation: A Study of Seoul, South Korea, 1970-1980. Sociological Forum, 6(4):641-659.

North, D. C. (2002). Kurumlar, Kurumsal Değişim ve Ekonomik Performans. Çev: Gül Çağalı Güven, İstanbul: Sabancı Üniversitesi Yayınları.

Özer, M. \& Biçerli, K. (2003-2004). Türkiye’de Kadın İşgücünün Panel Veri Analizi. Anadolu Üniversitesi Sosyal Bilimler Dergisi, 3(1): 55-86.

Polanyi, K. (2008). Büyük Dönüşüm - Çağımızın Siyasal ve Ekonomik Kökenleri (7. Baskı). Çev: A. Buğra, İstanbul: İletişim Yayınları.

Psacharopoulos, G. \& Tzannatos, Z. (1989). Female Labor Force Participation: An International Perspective. The World Bank Research Observes, 4(2).

Robinson, J. (2005). Female Labor Force Participation in the Middle East and North Africa. Wharton Research Scholars (No. 28).

Sorsa, P., Mares, J., Didier, M., Guimaraes, C., Rabate, M., Tang, G. \& Tuske, A. (2015). Determinants of the Low Female Labor Force Participation in India. OECD Economics Department Working Paper (No. $\mathrm{ECO} / \mathrm{WKP}(2015), 25)$.

Sönmez, P. (2006). Küreselleşme, Avrupa Birliği ve İstihdam: Çalışma İlişkilerinde Yaşanan Dönüşüm. Ankara Avrupa Çalışmaları Dergisi, 5(3): 177-98.

Taşseven, Ö., Altaş, D. \& Ün, T. (2016). Determinants of Female Labor Force Participation in OECD Countries. Uluslararası Ekonomik Araştırmalar Dergisi, 2(2): 27-38.

Tansel, A. (2014). Economic Development and Female Labor Force Participation in Turkey: Time-Series Evidence and Cross-Province Estimates. METU/ERC Working Paper (No.02/3). 
Thévenon, O. (2013). Drivers of Female Labor Force Participation in the OECD Countries. OECD Social, Employment and Migration Working Papers (No. 145).

Tutar, F. \& Yetişen, H. (2009). Türkiye'de Kadının Ekonomik Kalkınmadaki Rolü. Niğde Üniversitesi İ.̇̇.B.F. Dergisi, 3(2): 116-131.

United Nations (2015). The Millennium Development Goals Report 2015. USA. UNDP (2013). Democracy and Gender Equality: The Role of the UN. USA.

Uysal, D., Keskin, R. \& Sertkaya, Y. (2016). Türkiye'de Kadınların İşgücüne Katılımların Belirleyen Faktörler Üzerine Ekonometrik Bir Analiz. İktisadi Yenilik Dergisi, 3(2): 73-92.

Verick, S. (2014). Female Labor Force Participation in Developing Countries. IZA World of Labor Working Paper (No. 87).

$\mathrm{Xu}, \mathrm{L}$. (2015). Effects of Female Political Participation on Economic Growth: Evidence from Asian Countries. (Master Thesis), Swenska: Lund University School of Economics and Management.

Wacker, K., Cooray, A. \& Gaddis, I. (2017). Globalization and Female Labor Force Participation in Developing Countries An Empirical (Re-)Assessment, Globalization-Strategies and Effects. ed: B. J. Christensen ve C. Kowalczyk, USA: Springer.

World Bank (2011). World Development Report 2012 -GenderEqualityand Development. Washington DC.

World Bank (2018). World Development Indicators. http://databank.worldbank.org/data/repor ts.aspx?source=World-Development-Indicators (Erişim: 22.09.2018)

World Economic Forum (2018). The Global Gender Gap Report 2018. Geneva.

Yamak, R., Abdioğlu, Z. \& Mert, N. (2012). Türkiye'de İşgücüne Katılımı Belirleyen Faktörler: Mikro Ekonomik Analiz. Anadolu Üniversitesi Sosyal Bilimler Dergisi, 12(2): 41-58.

Yıldırım, K. \& Doğrul, G. (2008). Çalışmak ya da Çalışmamak:Türkiye'de Kentsel Alanlarda Yaşayan Kadınların İşücüne Katılmama Kararlarının Olası Belirleyicileri. Anadolu Üniversitesi Sosyal Bilimler Dergisi, 8(1): 239-262.

Zeren, F. \& Savrul, B. K. (2017). Kadınların İşgücüne Katılım Oranı, Ekonomik Büyüme, İşsizlik Oranı ve Kentleşme Oranı Arasındaki Saklı Koentegrasyon İlişkisinin Araştırılması. Yönetim Bilimleri Dergisi, 15(30): 87-103.

Zungura, M., Nyemba, E. \& Mutasa, F. (2013). The Relationship Between Democracy and Women Participation in Politics. Journal of Public Administration and Governance, 3(1): 168-176. 